\title{
A kis és közepes hatótávolságú rakéták és az új hiperszonikus fegyverrendszerek hatása napjaink biztonságpolitikájára m.resz
}

A tanulmány korábbi két része a kis és közepes hatótávolságú rakéták felszámolása érdekében kötött INF-szerződés előzményeivel foglalkozott. A szerző röviden összefoglalta a fegyverkezési verseny megállapodásának előzményeit, a hidegháború időszakát, majd az Amerikai Egyesült Államok szerződésből történő kilépésről szóló bejelentését és Oroszország válaszát elemezte. Az olvasók megismerték mindkét nagyhatalom egyezménysértő harci eszközét, az orosz Iszkander 9M729-est és az amerikai MK 41 rendszert. A cikksorozat záró része példákkal illusztrálja a két ország ellentétes érdekeit és álláspontját, majd a szerző felveti egy új biztonságpolitikai szerződés megkötésének igényét.

\section{Putyin a SzövetséGi Gyűlés előTT}

2019. február 20-án a Szövetségi Gyülésben Vlagyimir Putyin megtartotta évértékelő beszédét. Felszólalásában elsősorban az ország belügyeit érintő kérdésekre (a demográfiai helyzetre, a gazdaság teljesítőképességére, az orosz tudomány fejlődésére, az oktatás- és egészségügyre) tért ki. Elemezte a nemzetközi helyzetet, megemlítve az INF-szerződést, és annak következményeit. Ismét szóba hozta, hogy az MK 41 rendszer megsérti az INF-szerződést, és felolvasta a megállapodás erre vonatkozó részeit. Elmondta, hogy Oroszország csakis akkor telepít rakétákat, ha nem hagynak más megoldást számára, és nemcsak azokat az országokat veszi célba, ahonnan rájuk lőttek, hanem azokat is, ahol a döntéshozói tervezést végrehajtották.

Végül bejelentette, hogy idén tavasztól a Poszeidon önindítású torpedó a tengeri flotta speciális csapatainak rendelkezésére áll, és Oroszország közben egy új hiperszonikus rakétán, a Cirkonon dolgozik. Ez a rakéta 9 Mach sebességgel képes repülni, a hatótávolsága több mint $1000 \mathrm{~km}$. Vízi és földi célok megsemmisítésére egyaránt képes.

36. ábra. Poszeidon (korábbi nevén Status-6) interkontinentális, nukleáris meghajtású, nukleáris fejjel felszerelhető önirányítású torpedó. Egyes források szerint a maximális sebessége $200 \mathrm{~km} / \mathrm{h}$, maximális merülési mélysége több mint $1 \mathrm{~km}$. Összehasonlításként: a nukleáris meghajtású tengeralattjárók $60 \mathrm{~km} / \mathrm{h}$-val közlekednek, a torpedók sebessége $90 \mathrm{~km} / \mathrm{h}$

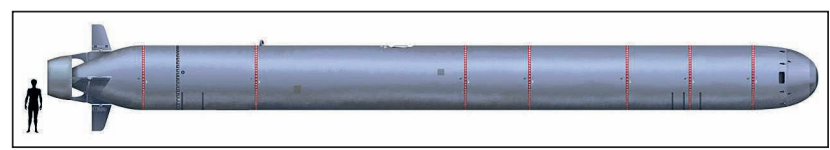

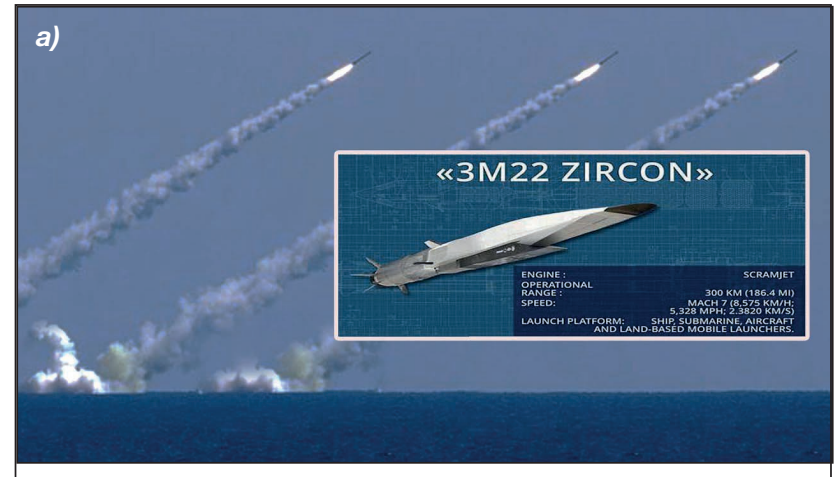

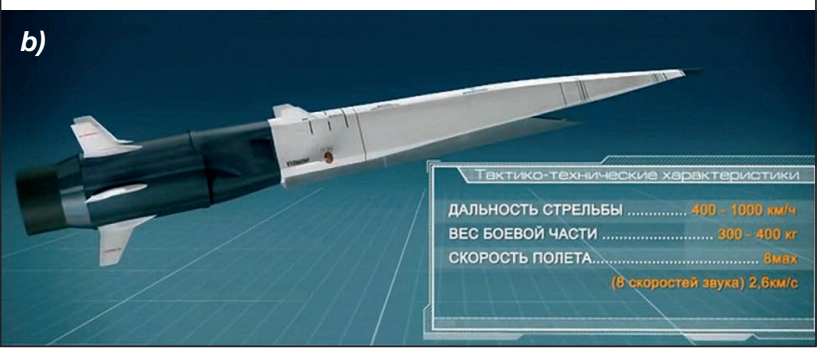

37. ábra. 3M22 Cirkon (3М22 „Циркон”) rakéta. Hajtóműve torlósugaras, lőtávolsága 300 km, sebessége 7 Mach 8,575 $\mathrm{km} / \mathrm{h}(2,3820 \mathrm{~km} / \mathrm{s})$, indítóállomás: hajó, tengeralattjáró, repülő, szárazföldi mobil indítóállomások (a). 3M22 Cirkon lőtávolság 400-1000 km, a harci rész tömege 300-400 kg, sebessége 8 Mach $(2,600 \mathrm{~km} / \mathrm{s})(\mathrm{b})$. A két képen eltérő adatok szerepelnek, egyelöre a hiperszonikus rakéta számos technikai jellemzőjéröl még nincs pontos adat

Putyin beszédének üzenete egyértelmű: Oroszország nem akar konfliktust és nem kíván fegyverkezni, de ha nincs más esélye, akkor az amerikai lépéseknek megfelelően válaszol. Amennyiben rálőnek, Oroszország visszalő [1].

38. ábra. 3M22 Cirkon. Lőtávolsága $350-500 \mathrm{~km}$, sebessége 8 Mach, hosszúsága 8-10 m

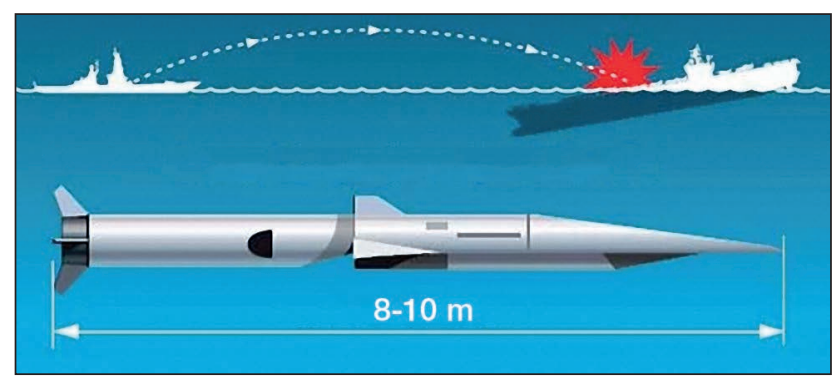

Hadnagy, MH vitéz Szurmay Sándor Budapest Helyőrség Dandár. ORCID: 0000-0002-8626-7122 


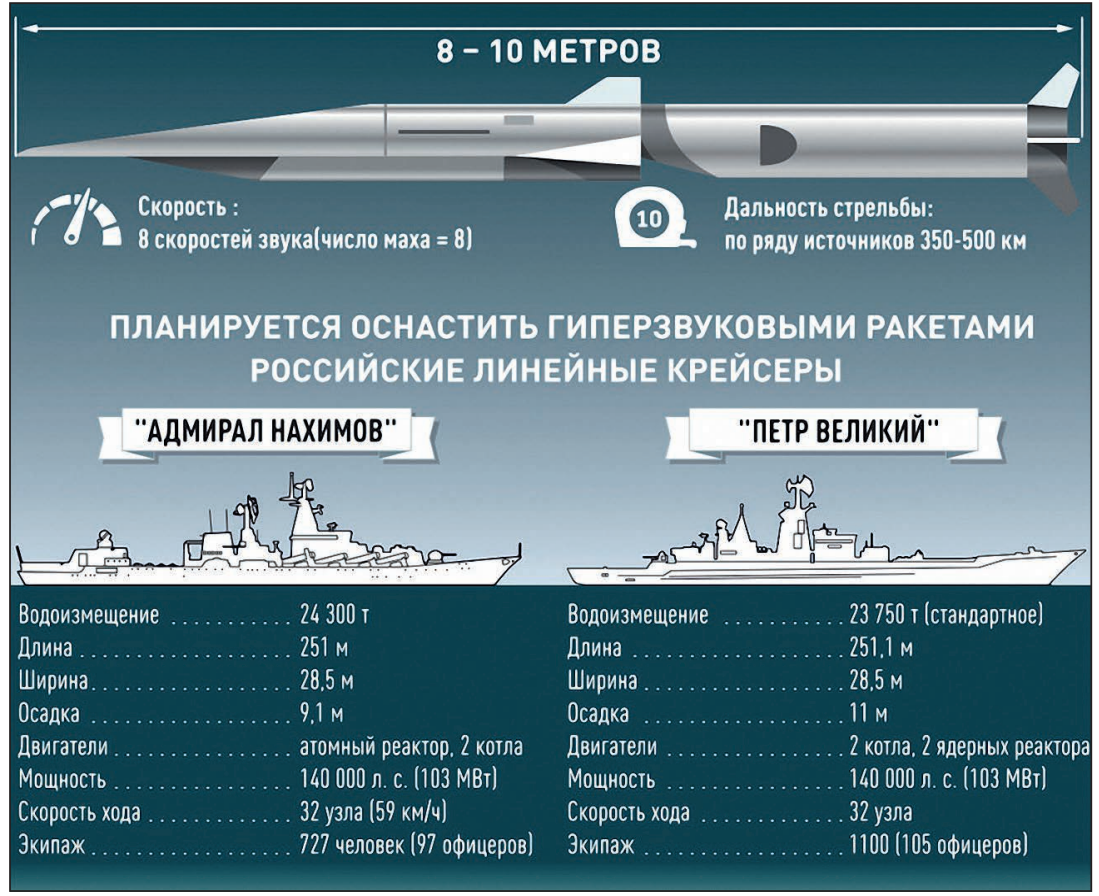

39. ábra. 3M22 Cirkon hiperszonikus rakéta. Hossza 8-10 m, sebessége 8 Mach, lőtávolsága 350-500 km. Jelenleg a következő rakétacirkálókra tervezik a felszerelésüket: ADMIRAL NAHIMOV, PJOTR VELIKIJ. Az ADMIRAL NAHIMOV jellemzői: vízkiszorítás 24300 t, hosszúsága $251 \mathrm{~m}$, szélessége $28,5 \mathrm{~m}$, hajótervezet 9,1 m. Meghajtás: atomreaktor, a 2 kazán teljesítménye 103 MW (140 000 LE), menetsebesség 32 kn (59 km/h). Legénysége 727 fő (97 tiszt). A PJOTR VELIKIJ jellemzői: vízkiszorítás $23750 \mathrm{t}$, hosszúsága $251,1 \mathrm{~m}$, szélessége 28,5 m, hajótervezet $11 \mathrm{~m}$. Meghajtás: 2 nukleáris reaktor, a 2 kazán teljesítménye 140000 MW (103 LE), 32 kn (59 km/h). Legénysége 1100 fő (105 tiszt)

\section{VALÓBAN HIDEGHÁBORÚ?}

A tanulmány korábbi részeiben utaltunk rá, hogy a jelenlegi állapotot megítélve, egyre több politikus emleget hidegháborús helyzetet. Ugyanakkor Putyin és Stoltenberg is hangsúlyozta, hogy nem tekinti céljának egy újabb fegyverkezési verseny kialakulását. A nyilvánosság felé történő kommunikáció ellenére, a stratégiai lépések és válaszok nyomán egyre egyértelműbb, hogy máris beált a hidegháborús helyzet. Hogy mikor kezdődött nem lehet egyértelműen megállapítani, de azt igen, hogy milyen események vezettek idáig, és milyen párhuzamok vonhatók a korábbi hidegháborús múlttal.

Az előzmények között szerepel az Egyesült Államok 2002-ben történt kilépése az ABM-szerződésből. Akkori-

40. ábra. A képen egy repülőgépre felszerelt Cirkon rakéta animációja látható

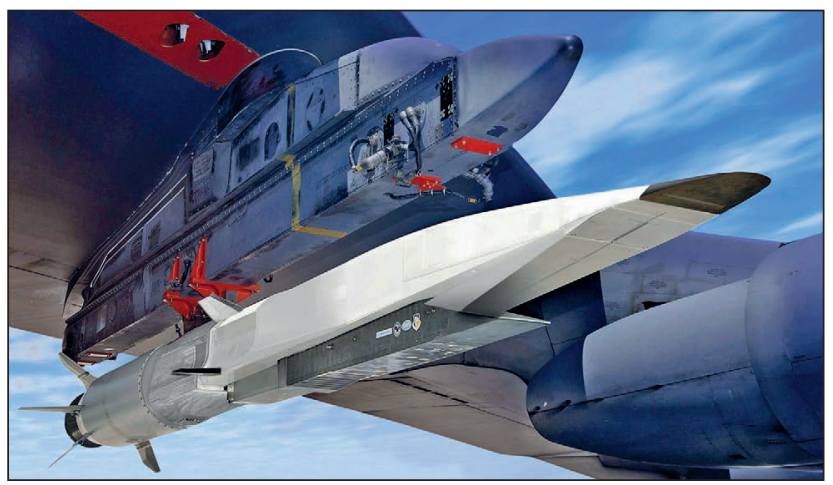

ban a két ország viszonya még nem volt ellenséges, de ez a lépés rosszul érintette Oroszországot. Bizalmatlanabbak lettek az Egyesült Államokkal szemben, úgy értékelték a helyzetet, hogy ezzel megbomlik a stratégiai egyensúly. Az USA döntése indirekt módon fegyverkezésre kényszerítette Oroszországot, mert ha az Egyesült Államok erős védelmi rendszerrel rendelkezik, akkor az egyensúly fenntartása érdekében nekik erős támadó rendszerrel kell rendelkezniük.

A két ország viszonyában a 2008-as orosz-grúz háború okozta az első komolyabb törést. Grúzia (2011-től magyarországi hivatalos elnevezése Georgia) ekkor már a NATO és az Egyesült Allamok támogatását élvezte, a grúz politikai vezetés szakított a közös szovjet múlttal. A grúz hadsereget a NATO képezte ki, a missziós tevékenységre napjainkban is a németországi Hohenfelsben készítik fel a grúzokat. A háború Mihail Szaakasvili akkori grúz elnök állítása szerint orosz agresszióval kezdődött, az oroszok megtámadták Grúziát. Oroszország állítása szerint a grúzok megtámadták Dél-Oszétiát, Abháziát, és Chinvaliban az orosz békefenntartókat. Természetesen a nyugati világ a grúz álláspontot fogadta el, még az amerikai Fox News televízióban megszólaltatott oszétok nyilatkozatait is folyamatosan megszakították az újságírók, mert grúz agresszióról beszéltek.

A tények elemzésekor egyértelműen kiderült, hogy Oroszországnak volt igaza, de a két tömb közötti törés már bekövetkezett. A konfliktus előtt sokak számára úgy tűnt, hogy az Oroszországi Föderáció Fegyveres Erői már képtelenek hatékony csapást mérni, az egykori szovjet hadsereg ütőereje már a múlté. Annak ellenére, hogy a rosszul felfegyverzett orosz hadsereg valóban válságban volt, legyőzte a NATO által kiképzett grúzokat, tehát a világ újra felfigyelt Oroszországra [2, 3].

41. ábra. A 3M-14E Kalibr robotrepülőgépet hadihajók ellen fejlesztették ki. Technikai jellemzői: robbanó vagy kazettás robbanófej, tömege $450 \mathrm{~kg}$. Átmérője $533 \mathrm{~mm}$, hosszúsága $6,20 \mathrm{~m}$. Repülési sebesség 0,8 Mach $(880 \mathrm{~km} / \mathrm{h})$, indulótömege $1770 \mathrm{~kg}$, repülési távolsága $300 \mathrm{~km}$. Röppályájának magassága szárazföldön $50-150 \mathrm{~m}$, vízen $20 \mathrm{~m}$. Egyesével és csoportosan is indítható

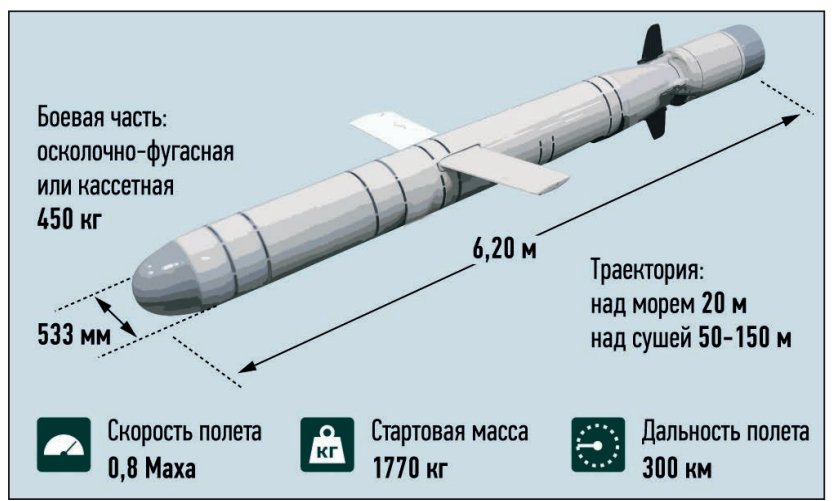




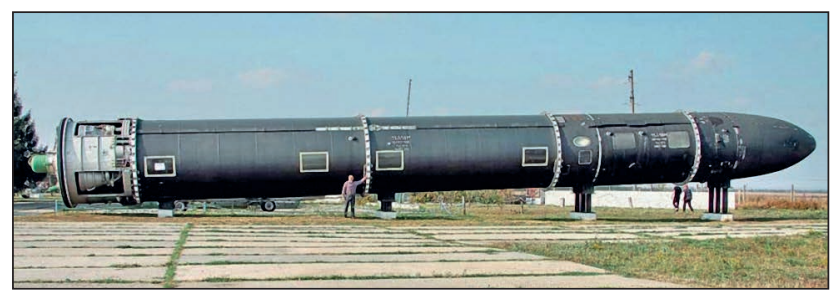

42. ábra. A Szarmat mérete egy emberhez viszonyítva. A ballisztikus rakéta számos technikai jellemzője nem nyilvános

Az orosz-grúz háború után a két nagyhatalom viszonya még közel sem volt annyira nyíltan ellenséges, mint napjainkban. Az igazán komoly törés 2014-ben következett be, amikor Ukrajnában győzött a nyugatbarát „Majdan forradalom". Viktor Janukovics ukrán elnököt megbuktatták, el kellett menekülnie az országból. Ukrajnában azonban nem mindenki volt híve (és most sem az) a nyugati integrációnak, mivel az ország keleti részeiben pl.: Donyeck, Luganszk, Krím, a lakosság többsége orosz. A Krím-félsziget lakosságában az orosz nemzetiségűek aránya minimum 60, maximum 90\%. A kijevi Majdan forradalomban tevékeny részt vállaltak az ukrán szélsőséges nacionalisták, ez azonban az ukrajnai oroszokból komoly ellenérzéseket váltott ki. Ennek következményeként a Krímben népszavazást írtak ki arról, hogy kiváljanak-e Ukrajnából, és csatlakozzanak-e az Oroszországi Föderációhoz. Nyugaton azonban nem ismerték el a népszavazás legitimitását, úgy értékelték a helyzetet, hogy Oroszország annektálta a Krím-félszigetet. Komoly agressziónak értékelték e lépését, amellyel az oroszok megsértették Ukrajna szuverenitását. Ekkor kezdődtek meg Oroszország ellen azok a szankciók, amelyek a mai napig is tartanak. A NATO ugyanabban az évben telepítette Romániába a rakétavédelmi rendszert. Egyértelműen 2014 volt az az esztendő, amikor megváltozott a korábban kialakult biztonságpolitikai helyzet.

Ettől az időponttól kezdve egyre jobban felfedezhetők a hidegháborús vonások. Ezek egyik jele a helyi konfliktusokban érhető tetten. A hidegháború idején a két nagyhatalom, a Szovjetunió és az USA nyíltan nem ütközött meg egymással, ehelyett a helyi konfliktusokat használták fel arra, hogy egymás ellen harcoljanak. Ezt példázta a koreai, a vietnámi és az afganisztáni háború is, amelyekben mindkét ország támogatott egy-egy résztvevő felet, ily módon harcolva egymás ellen. Napjainkban szintén léteznek hasonló fegyveres konfliktusok. Ukrajnában, a már említett krími események után a Donyeck-medencében polgárháború tört ki. A kijevi kormánycsapatokat az amerikaiak támogatják, a donyecki felkelőket pedig az oroszok. A szíriai hadszíntér is hasonlóan tagolt. Szíriában 2011-ben, az „arab tavasz" idején felkelések kezdődtek Bassár el-Aszad elnök ellen. A nyugati világ a felkelők oldalára állt, majd pedig Aszad kérésére 2014-ben, a kormányerők oldalán az

43. ábra. A Brit Királyi Haditengerészet Tomahawk robotrepülögépe

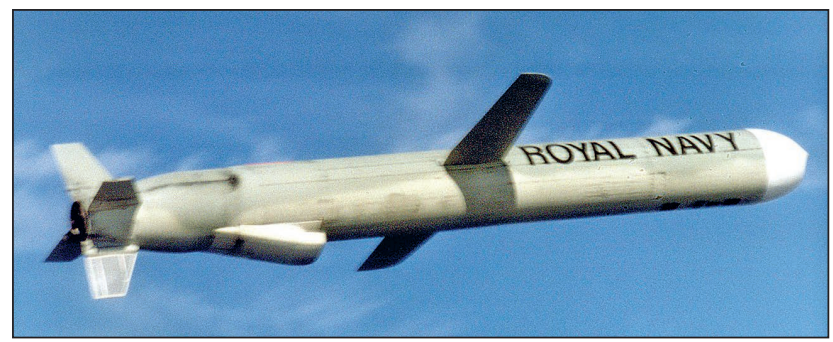

oroszok is bevonultak a térségbe. Jelenleg hasonló események zajlanak Venezuelában is. 2019-ben Juan Guaido azzal az indokkal kiáltotta ki magát elnöknek, hogy a jelenlegi elnök, Nicolas Maduro diktátor törvénytelen módon ragadta magához a hatalmat, és ő tehető felelőssé az országos éhezésért. Az amerikaiak Guaido oldalára álltak, az oroszok Maduro-t támogatták. Az ellentét legfőbb forrása, hogy a korábbi elnök, Hugo Chavez államosította az olajvállalatokat, kivéve amerikai cégek kezéből az irányítást. Chavez Oroszországgal és Kínával kezdett kereskedni, utódja Maduro ugyanezt a politikát folytatja.

A médiában 2014-ben kezdődött a hisztériakeltés. Amikor a Krím Oroszországhoz került, cikkek jelentek meg arról, hogy Oroszország a balti államokat is bekebelezheti és Lengyelország is veszélyben lehet. Sőt, bizonyos nyugati országok olyan szintre fejlesztették ezt a képességet, hogy a tájékozatlan olvasó szinte úgy érezze, Oroszország bármelyik percben támadhat. Ugyancsak állandó téma a beépített orosz ügynökök aktív tevékenysége, valamint a Putyin-Trump összeesküvés-elmélet. A háttérben az a politikai stratégia működik, hogy a valós és álhírek összekeverésével felnagyítsák az oroszoktól való félelmet.

Ugyancsak a hidegháború időszakát idézik a sportban lévő ellentétek. Nem a valóságos sporteredményekről, hanem a terület átpolitizáltságáról van szó. A hidegháború idején, 1980-ban a nyugati országok Afganisztán szovjet megszállására hivatkozva bojkottálták a moszkvai olimpiát. Válaszlépésként a szocialista országok bojkottálták az 1984-es Los Angeles-i olimpiát.

\section{Összegzés}

Az 1987-ben megkötött INF-szerződés kezdetben még sikeresnek volt mondható, ám egyenlőtlenségek már akkoriban is tapasztalhatók voltak az egyezményben. A szerződés egyértelműen Amerikának kedvezett, és a szovjeteket hátrányos helyzetbe hozta. Mégis a szerződés tovább élt, az első komoly próbatétel az ABM 2002-es megszűnése volt. Amerika egyoldalúan kilépett a szerződésből Oroszország nem tetszésének ellenére, de az INF mellett mindketten kiálltak. Amikor az Egyesült Államok 2014-ben Romániába rakétákat telepített, lépésével már komolyan sértette Oroszországot, amely azt állította, hogy ez már az INFszerződés megszegése. Az USA és a NATO válaszul Oroszországot vádolta ugyanezzel. Végül 2018-ban Amerika bejelentette szándékát, hogy kilép a szerződésből,

44. ábra. MiG-31 elfogó vadászgép Kinzsal rakétával felszerelve. A Kinzsal az Iszkander rakéta átalakított, repülöre szerelhető változata. A rakéta lőtávolsága 2000 km

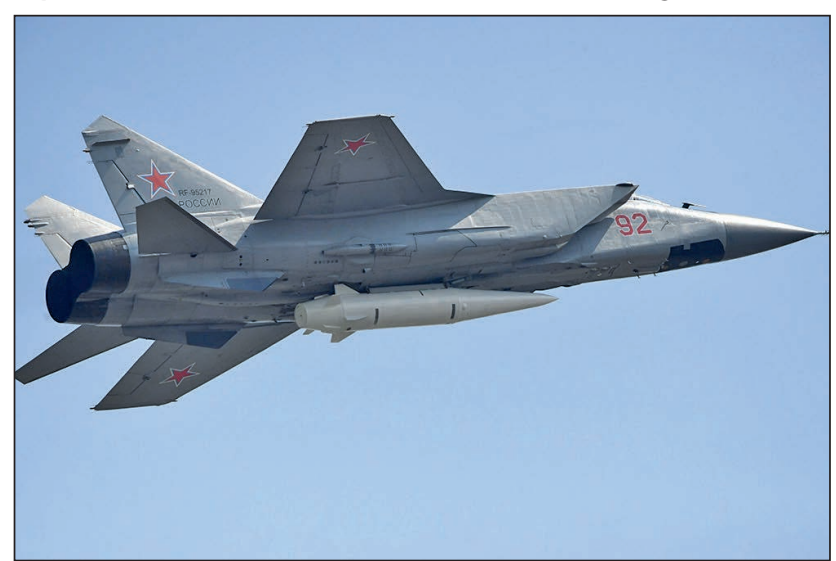


amennyiben Oroszország nem tesz eleget a kötelezettségeinek. Oroszország továbbra is tagadta a vádakat, és ők az amerikaiakat vádolták. Végül 2019. február 1-jén megszűnt a szerződés.

Mint láthattuk, ezután mindkét ország azt álította, hogy nem akarnak ténylegesen rakétákat telepíteni Európába, csak akkor, ha a másik fél nem hagy nekik más megoldást. Ukrajna egyfajta ütközőzóna lehet, mivel ők kívánatosnak tartanák, ha területükre amerikai rakéták kerülnének. Amennyiben Ukrajnába MK 41 rendszert telepítenek, azt Oroszország úgy fogja értékelni, mintha a NATO és Amerika megkezdte volna rakétáinak Európába történő telepítését. Ebben az esetben, válaszként Oroszország is új rakétákat telepít. Természetesen a NATO válasza az lesz, hogy az MK 41 nem sérti a szerződést, Oroszország ok nélkül telepít fegyvert, ezért a NATO-nak is válaszolnia kell a fenyegetésre.

A megoldás a helyzet megfelelő rendezése érdekében az lenne, ha a felek tárgyalásokat kezdenének egy új szerződés létrehozásáról. Az új egyezménybe kívánatos lenne bevonni azokat az országokat is, amelyek szintén rendelkeznek ilyen típusú fegyverekkel (pl. Kína), de az INF-nek korábban nem voltak tagjai, mivel a stratégiai egyensúlyt csak velük közösen lehet(ne) fenntartani. A szerződésben minden más fegyvertípusról is rendelkezni szükséges azokról is, amelyekről az INF korábban nem rendelkezett -, hogy egyik nagyhatalom se kerülhessen fölénybe a másikkal szemben. (Az INF-szerződésben pl. csak a szárazföld- ről indítható rakéták szerepeltek, a tengerről indíthatók nem. Ez utóbbiakkal annak idején csak az Amerikai Egyesült Államok rendelkezett, a szovjetek nem. Ma már mindkét fél rendelkezik ezekkel a rakétákkal.) Szükségesnek látszik a NATO Európába települt rakétavédelmi rendszereiről történő tárgyalás mielőbbi megkezdése, mert azok valóban megsértik az eredeti szerződés IV. cikkelyét. Ugyanakkor Oroszország új típusú fegyvereinek szabályozását is napirendre kell tűzni, hogy a világ elkerülje a fegyverkezési versenyt. Egy átfogó, új leszerelési szerződés megkötése nélkül egyre közelebb kerülünk egy újabb nagyobb konfliktushoz.

\section{FELHASZNÁLT IRODALOM}

[1] Putin Gets Serious: If Europe Accepts US Missiles, Russia Will Rearm and Retaliate! Youtube 2019. febr. 20. Elérés 2020. március 24. https://www.youtube. $\mathrm{com} /$ watch?v=NMeCzo2zMV0;

[2] „Putin's Military Reforms: 20 Years Later and Russia Has an Army Again, National Pride Again!" Youtube 2019. febr. 25. Elérés 2020.március 24. https://www. youtube.com/watch?v=6a7OsT_F1fw;

[3] Venal American Media FOX NEWS about South Ossetian Conflict Youtube. Elérés 2020. március 24. https://www.youtube.com/watch?v=9fBGtXS66VM.

\section{HM ZRÍNYI TÉRKÉPÉSZETI ÉS KOMMUNIKÁCIÓS SZOLGÁLTATÓ KÖZHASZNÚ NKFT.}

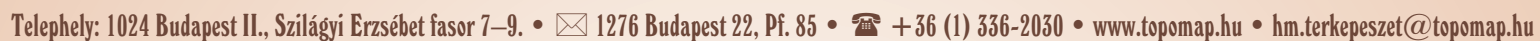

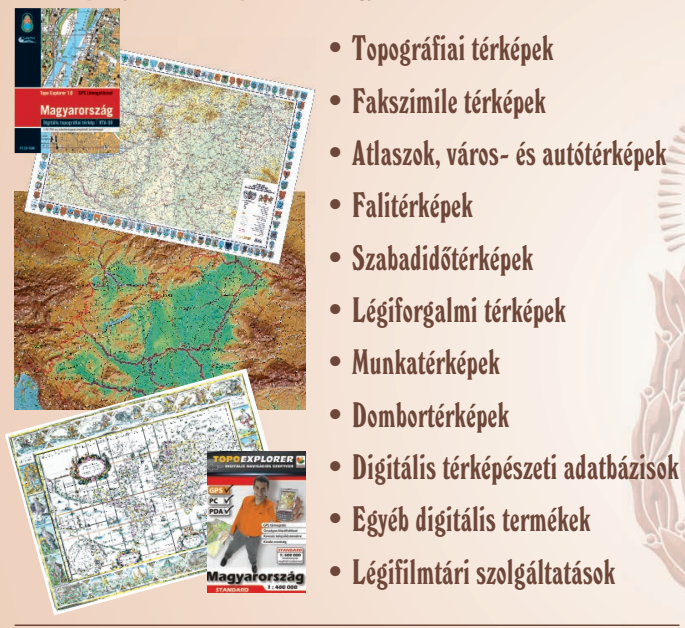

ÜGYFÉLSZOLGÁLAT ÉS TÉRKÉ́PBOLT:

1024 Budapest II., Fillér u. 14.

욜 +36 (1) 212-4540・uggyfelszolgalat@topomap.hu Nyitva tartás: hétfó-péntek 9.00-15.00
- PrePress - Nyomdai elökészítés

- szövég-grafika- és képfeldolgozás, kiadványszerkesztés

- ellenőrző nyomatok, digitális proofok előállitása

- bel-és kültéri tablók, bannerek nyomtatása

- hagyományos és elektronikus montírozás, színrebontás

- nyomóformák elóállítása nyomdai filmról, illetve CTP-technológiával

- Gyorssokszorosítás

- színes és fekete-fehér másolás/nyomtatás 330 x 487 mm méretig

- Press - Nyomtatás

- ofszetnyomtatás négy-, illetve hatszínnyomó gépeken, 89 x 126 cm méretig

- PostPress - Kötészeti feldolgozás

- felületnemesítés fóliázással, laminálással 167 cm szélességig

- hajtogatás, spirálozás, sorszámozás

- összehordás, irkakészítés, ragasztókötés

- kasírozás, táblakészítés, aranyozás

- szortiment könyvkötészet

- Vákuumformázás

- vákuumformázó szerszámok, terepasztalok előállítása CNC-technológiával - vákuumformázás

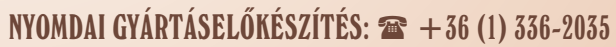

